\title{
Adoption of Brush Busters: Results of Texas county exten- sion survey
}

\author{
URS P. KREUTER, HEIDI E. AMESTOY, DARRELL N. UECKERT, AND W. ALLAN MCGINTY
}

Authors are assistant professor and graduate research assistant, Dept. of Rangeland Ecology and Management, Texas A\&M University, College Station, Tex. 77843; professor, Texas Agr. Exp. Sta., US Hwy. 87 North, San Angelo, Tex. 76901; and professor, Texas Agr. Ext. Service, US Hwy. 87 North, San Angelo, Tex. 76901

Abstract

Changing landowner demographics and the increasing recognition that some quantity of woody plants is valuable for certain rangeland management objectives has led to increasing interest in selective brush management practices. Brush Busters is a collaborative extension/research program developed in response to this growing interest. A survey of Texas County Extension Agents-Agriculture was conducted in 1999 to determine their perceptions about the interest in and adoption of Brush Busters practices. Using 3 threshold photographs, Extension Agents representing almost $50 \%$ of the counties in the 9 Extension Districts surveyed estimated that 44,34 , and $49 \%$ of the total area of mesquite, juniper and pricklypear, respectively, could be treated using Brush Busters. They also indicated that over 405,000 ha (78\% mesquite) were treated with Brush Busters methods between 1995 and 1998, but that this represented less than $7 \%$ of the potentially treatable area. In most Extension Districts, more time was spent disseminating information about Brush Busters methods than any other brush management method since 1995. Extension Agents indicated that Brush Busters has become popular because it is perceived to be an inexpensive, convenient, safe, effective and predictable method for controlling brush, and because user-friendly information is widely available. Our findings suggest that increasing the adoption rates of ecologically sound rangeland management technologies requires: (1) greater emphasis on developing and disseminating user-friendly messages to rangeland managers and Extension Agents; and (2) greater emphasis on short-term efficacy rather than the long term advantages of new technologies.

Key Words: agency and industry partnerships, brush management, collaborative marketing, information dissemination, technology adoption

The assumption that ranchers are profit maximizers and that good managers can adopt technology are common among technology developers (White 1987, Workman 1986). However, the adoption of new technology by land managers is affected by many factors other than productivity including perceived risk and uncertainty (Zepada 1994). Fliegel (1993) proposed a technology adoption model for land managers in which the interaction of community characteristics (age, education, income, size of farm

Research was funded through a gift from Dow AgroSciences LLC and a Texas A\&M University Faculty Mini-Grant.

Manuscript accepted 3 Feb. 2001.

\section{Resumen}

El cambio demográfico de la propiedad de la tierra y el mayor reconocimiento de que alguna cantidad de plantas leñosas es valiosa para ciertos objetivos de manejo de pastizales ha conducido a aumentar el interés de practicas selectivas de manejo de arbustos. Los Quebradores de Arbustos es un programa colaborativo de extensión/investigación desarrollado en respuesta de este creciente interés. En 1999 se condujo un muestreo entre los agentes agrícolas municipales de extensión de Texas para determinar sus percepciones acerca del interés en y la adopción de prácticas de quebrado de arbustos. Utilizando 3 fotografías de umbral, los Agentes de Extensión representaron casi el 50\% de los municipios en los 9 Distritos de Extensión muestreados, estimando que 44, 34 y 49\% del área total de "Mesquite", "Juniper" y "Pricklypear", respectivamente, pudieran ser tratados utilizando quebradores de arbustos. Ellos también indicaron que entre 1995 y 1998 más de 405,000 ha (78\% "Mesquite") fueron tratadas con métodos de quebrado de arbustos, pero que esta superficie representó menos del $7 \%$ del área potencialmente tratable. Desde 1995, en la mayoría de los Distritos de Extensión, se gastó mas tiempo diseminando información acerca de los métodos de quebrado de arbustos que cualquier otro método de manejo de arbustos. Los agentes de extensión indicaron que los quebradores de arbustos han venido a ser más populares porque se percibe que es un método barato, conveniente, seguro, efectivo y predecible para controlar arbustos, y porque hay disponible mucha información de fácil comprensión respecto a ellos. Nuestros hallazgos sugieren que para incrementar las tasas de adopción de tecnologías que facilitan el manejo de los pastizales con sentido ecológico se necesita: (1) un mayor esfuerzo en desarrollar y diseminar mensajes de fácil comprensión para los manejadores de pastizales y Agentes de Extensión y (2) Se debe enfatizar en la eficacia de las nuevas tecnologías a corto plazo en lugar de las ventajas a largo plazo.

and tenure status) social participation in farm and/or community organizations, and communication factors (extension contact, print media contact, and radio contact) affect the rate of technology adoption. Yet, Barao (1992) pointed out that psychological and behavioral aspects of technology adoption are often less tangible than physical or economic constraints to technology adoption. For example, while it is often assumed that level of education positively impacts the rate of adoption of new technology, Rowan and White (1994) did not find this relationship in a survey of Texas ranchers. A 1989 survey of South Texas Ranchers, identified range condition, forage quantity, and past experience as being the most important factors affecting decisions about live- 
stock stocking rates, while economics was moderately important and agency personnel and neighbors were generally of low importance (Hanselka et al. 1991).

Rowan et al. (1994) found that land managers' decisions about adopting weed and brush management technologies were often negatively affected by neighbors' attitudes and fear of treatment methods, especially the use of fire. They also found that the amount of brush control was negatively correlated with the proportion of offranch income but positively correlated with the proportional income from livestock. In addition, Hanselka et al. (1990) reported that quality and quantity of herbage production, amount of rainfall (which affects the success of weed and brush control treatments), livestock management considerations, and projected economic efficacy were major factors affecting landowners' decisions about initiating weed and brush management. Once the decision is made to implement a treatment, factors influencing which weed or brush management technique is to be used include, plant community structure, plant size and density, treatment costs, projected economic returns, and personal experience.

Intensified livestock grazing and reduced fire frequency on US rangelands has resulted in a change in the grasswoody plant interaction (Scifres 1980, Archer and Stokes 2000), which has led to widespread transformation of grasslands to shrublands, savannas and woodlands (Archer 1989, 1994, Schlessinger et al. 1990), and a decline in water yield from rangelands (Douglass 1983, Jofre and Randal 1993, Thurow et al. 2000). The resulting decline in rangeland productivity has led to significant investment in brush removal on US rangelands, especially since the 1960s (Bovey 1998). However, since the 1980s, increasing recognition of the potential value of some quantity of woody plants on rangelands has resulted in increasing emphasis on the use of integrated brush management systems to achieve diverse management goals (Scifres et al. 1983, Hanselka et al. 1996). While there has been a shift in brush control emphasis, economic analyses of alternative brush management practices have, with few exceptions (Kreuter et al. 1996), ignored the opportunity cost of not controlling brush (Teague et al. 2001, Kreuter et al. 1999). The increasing interest since the mid-1980s in wildlife as a source of revenue on Texas rangelands has led to a greater focus on more selective, and less costly brush management techniques that enhance wildlife habitat (see for example Fulbright 1997).
One such program is Brush Busters which was developed in 1995 as a collaborative program of the Texas Agricultural Experiment Station (TAES) and the Texas Agricultural Extension Service (TAEX) at San Angelo. The purpose of this program was to expedite the adoption of select "individual plant treatments" (IPT) for controlling brush by using environmentally friendly herbicides, and by targeting younger, more susceptible plants in order to increase the effectiveness and decrease the cost of herbicide applications (Ueckert 1997, Ueckert et al. 1999). Specific Brush Busters programs have been developed for mesquite (Prosopis glandulosa Torr.) in 1995, juniper (Juniperus ashei Buchh. and J. pinchotii Sudw.) in 1996, prickly pear (Opuntia spp.) and other cactus species in 1997, and for huisache (Acacia smalii (L.) Willd.) in 2000. To date, Brush Busters has received wide interest among Texas landowners, but the specific reasons for its popularity have not been explicitly addressed. The high adoption rate of the Brush Busters approach to IPT provides a timely opportunity to identify those factors that enhance the adoption of technologies aimed at improving rangeland conditions.

In the summer of 1999 , we conducted a survey of TAEX County Agricultural Extension Agents-Agriculture to take advantage of this opportunity. The objectives of the study were: (1) to obtain general information about brush management in Texas; (2) to estimate the area in Texas of mesquite, juniper, and pricklypear potentially treatable with Brush Busters methods; and (3) to determine Extension Agents' perceptions about the level of adoption of Brush Busters by landowners relative to other brush management practices, and the factors affecting landowners' interests in this approach to brush management. This paper reports the survey result from which we were able to draw conclusions not only about the potential for individual plant brush control in Texas, but also about the lessons that Brush Busters provides for the adoption of other rangeland management practices.

\section{Methodology}

The objectives of the study were achieved through the analysis of survey data obtained from County Extension Agents-Agriculture (hereafter referred to as Extension Agents) throughout Texas. A self-completion mail survey questionnaire was used to gather information about the county, extension-related activities, general brush management issues in each respondent's county, and about the use of Brush Busters. Three photographic images showing threshold conditions for mesquite, juniper and pricklypear were appended to the questionnaire to provide survey participants the same point of reference in answering questions about the density of these 3 species. The threshold conditions were based on estimated maximum plant height and/or plant density that is treatable using Brush Busters.

The survey questionnaire was mailed in April 1999 to 250 Extension Agents serving all 254 Texas Counties. The survey was administered using the multiple follow-up procedures of the "Total Design Method" popularized by Dillman (1978). The 4-stage procedure consisted of: (1) Day 1 - mail questionnaire and cover letter explaining the purpose of the survey; (2) Day 10 - mail reminder card to nonrespondents; (3) Day 21 - mail reminder letter with a second copy of the questionnaire to non-respondents; and (4) Day 28, mail final reminder card.

To compare data from different parts of the State, counties were categorized according to the 12 Texas Agricultural Extension Districts. Numerous Extension Agents from counties east of Highway I35 reported that mesquite, juniper, and pricklypear management was not applicable in their areas. Because our survey focused on the management of brush species that have been incorporated into Brush Busters by 1999, we excluded the counties in the North, East, and Southeast Extension Districts from the analysis. A total of 192 counties in the remaining 9 Extension Districts were thus included in the analysis.

In a few areas of inquiry, some the Extension Agents were internally inconsistent in answering replicate questions. We excluded from the analysis responses to replicate questions that differed by more than $10 \%$ because of uncertainty about which response was correct. Thus the sample size (n) was not constant for all the areas of inquiry. Simple descriptive statistics were used to compare data from the Extension Districts.

\section{Results}

Of the 192 Texas counties in the 9 Extension Districts included in the study (Fig.1), we received 164 responses. While the overall response rate was $85.4 \%$, response rates varied ranging from a high of $100 \%$ in the Southwest district, to a low of $68 \%$ in the Rolling Plains district. The results of the study are represented in 3 


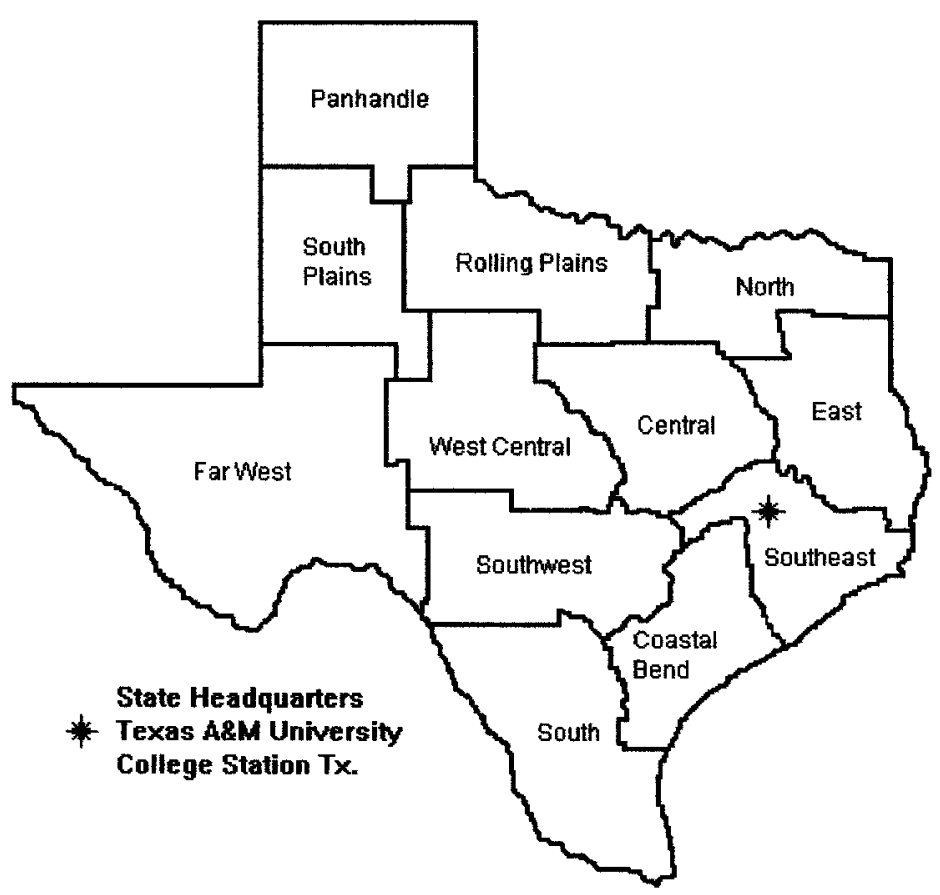

Fig. 1. Texas Agricultural Extension Districts

parts: (1) ranch demographic information, (2) general brush management, and (3) Brush Busters.

\section{Ranch Demographic Information}

Across all 9 Extension Districts included in the analysis, the greatest proportion of landholdings occurred in the 10 to 40ha $(34 \%)$ and 41 to 404 -ha $(33 \%)$ size categories. While the proportional representation in these size categories was substantially greater in the Central, Southwest, Coastal Bend, and South districts and lower in the Panhandle and Far West districts, the responding Extension Agents indicated that the number of ranches in these categories increased in all 9 districts since 1990. By contrast, ranches greater than 404 ha in size were proportionately fewer across all 9 Extension Districts $(405-1,215$ ha $=13 \%, 1,216-4,045$ ha $=$ $10 \%$, and $>4,045 \mathrm{ha}=10 \%$ ), except in the Far West district where ranches exceeding 4,045 ha were most numerous $(47 \%)$. In virtually every district the proportion of ranches greater than 405 ha in size has decreased over the last 10 years. This demographic shift towards landholdings of less than 405 ha suggests a potential overall shift in land use and management objectives. For example, based on anecdotal information about the amount of time spent by Extension Agents in disseminating rangeland-related information, the decline in the size of landholdings appears to be associated with a shift in management emphasis from livestock to wildlife in the Edwards Plateau and South Texas burning, aerial herbicide applications, biological methods, and other treatments. In each Extension District, we then ranked the average time spent on each of the 7 brush management categories; 1 and 7 being assigned to the categories to which the most and least amount of time was allocated, respectively. In all but 2 of the 9 Extension Districts analyzed (South Plains and Coastal Bend) most time was spent on disseminating information about Brush Busters methods. There was greater variation in the proportional amount of time spent disseminating information about other brush management methods. Across all 9 Extension Districts, the average rank values for brush treatment methods were: 1.3 for Brush Busters, 2.2 for other IPTs, 3.2 for mechanical treatments, 4.3 for prescribed burning, 4.8 for aerial herbicide applications, 5.8 for biological methods, and 6.3 for other treatments.

Extension Agents were subsequently asked to rank their perceptions of the interest among landowners in various brush control techniques (Fig. 2), and to indicate how interest in these techniques have changed since 1995. Although, on average, the Extension Agents did not perceive there to be a strong interest (i.e., > 4) by landowners in any brush control technique, the survey did indicate above average interest in Brush Busters for all 3 species, and somewhat above average interest in dozing/grubbing for mesquite and juniper, and average interest in prescribed burning for all 3 species. Mean values of $>4$ (i.e., above average-to-great landowner interest) were recorded for the

\section{General Brush Management}

Extension Agents were asked to indicate the amount of time that they spend disseminating information about Brush Busters, other individual plant treatments (IPT), mechanical treatments, prescribed
Plains areas (West Central, Southwest, and implications for rangeland ma practices implemented by landowners, including brush management.

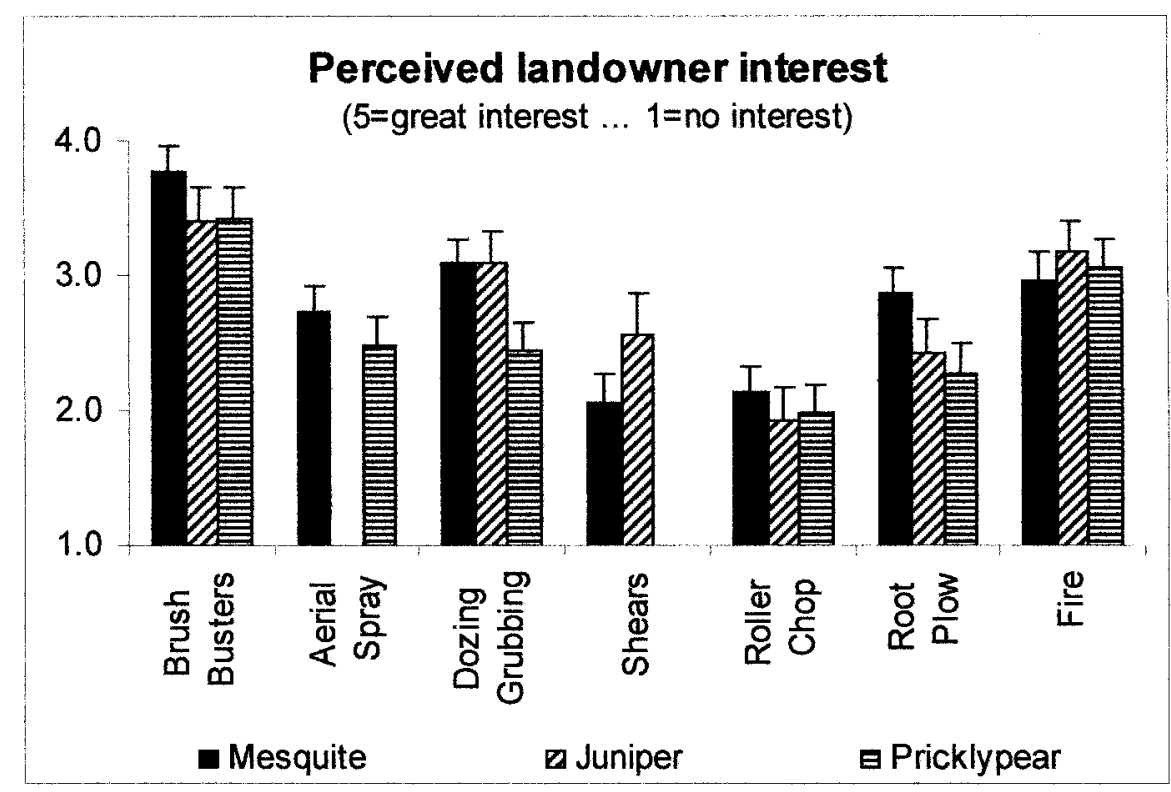

Fig. 2. Average of Extension Agents' perceptions regarding landowners' interests in various brush control techniques. (Data dispersion bars represent $95 \%$ confidence limits.) 

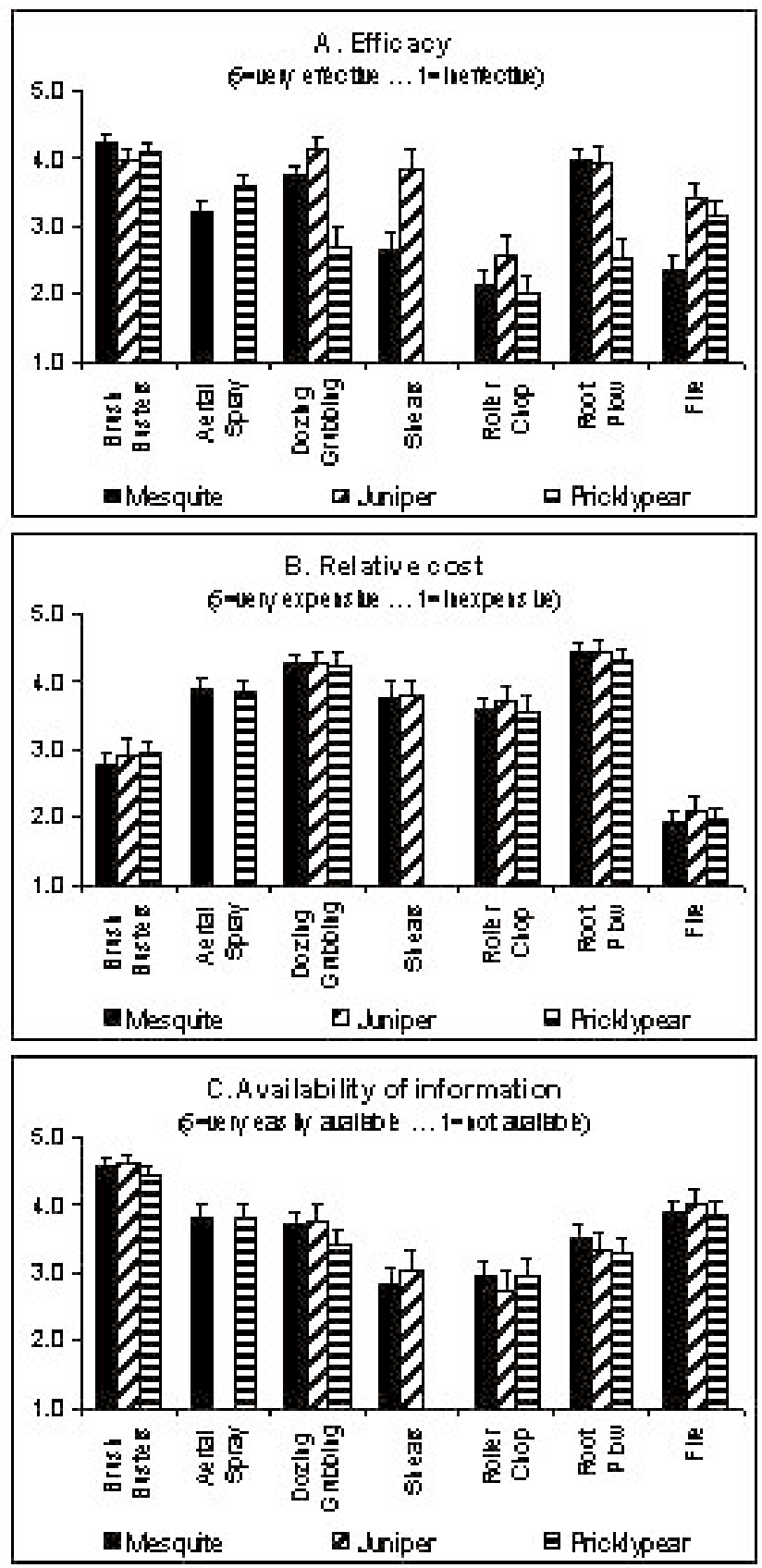

Fig. 3. Perceived comparative efficacy, cost effectiveness, and availability of information about specific brush control techniques for mesquite, juniper, and pricklypear. (Data dispersion bars represent $95 \%$ confidence limits.)

use of Brush Busters on all 3 species in the West Central Extension Districts, and for the use of Brush Busters for mesquite and juniper in the Central Extension District. The other treatment types were, almost without exception, valued at $<4$ (and in many cases at $<3$, i.e., below average interest) in virtually all Extension Districts. However, on average, Extension Agents also reported that there has been an increase in landowner interest in Brush Busters and the use of prescribed fire for controlling all 3 species, as well as in the use of dozing/grubbing, hydraulic shears, and root plowing for controlling juniper.

In the same series of questions about various types of brush management, Extension Agents were also asked to rank on a scale of 1 to 5 their impressions about the efficacy, cost effectiveness, and availability of information on specific brush control techniques (Fig. 3). On average, the Extension Agents ranked Brush Busters as high or higher in terms of effi- cacy than any other brush control technique for mesquite and prickly pear, and almost as high as dozing/grubbing for juniper (Fig. 3, panel A). Root plowing was also considered to be effective for mesquite and juniper as was the use of hydraulic shears for juniper. Prescribed fire was considered to be of average efficacy for juniper and prickly pear. While hydraulic shears are an effective control method for $J$. ashei, this method is often ineffective for $J$. pinchotii unless the shearing is accompanied by herbicide treatment on the cut stump. The high rank value assigned to the hydraulic shears for juniper may be because Extension Agents addressed the question only in terms of $J$. ashei, which dominates in many areas, or it may reflect a lack of knowledge among the respondents about the resprouting characteristics of $J$. pinchotii when it is cut.

Extension Agents also considered Brush Busters to be substantially less expensive than the other treatment types, except fire, for all 3 species (Fig. 3, panel B). Combining efficacy and cost effectiveness, therefore, appears to place Brush Busters considerably ahead of alternative brush control techniques in the eyes of the Extension Agents, especially for mesquite.

They also indicated that information was more readily available about Brush Busters than other techniques, although information about prescribed fire also seemed to be readily available (Fig. 3, panel C).

\section{Brush Busters}

From the preceding results, it is apparent that Brush Busters has attracted considerable interest and, compared to other brush management approaches. It is positively regarded by many of the Extension Agents, in terms of its efficacy, relatively low cost, and availability of information.

The survey participants were asked to estimate the total area of mesquite, juniper and pricklypear in their county, and using 3 photographs that showed threshold vegetation conditions for the use of Brush Busters methods, to estimate the potential area suitable for Brush Busters applications in each county. The cumulative responses from the counties that submitted useable responses are presented in Table 1 , while the total size of each district and the combined area of the counties with useable responses are included in Table 2. The estimates provided by some Extension Agents were excluded from the analysis because of inconsistencies between 2 replicate questions. Thus, the number of counties $(\mathrm{N})$ used to derive the area esti- 
Table 1. Estimated total area of mesquite, juniper and pricklypear, and Brush Busters (BB) treatable area of each species.

\begin{tabular}{|c|c|c|c|c|c|c|c|c|c|}
\hline \multirow{3}{*}{ District name } & \multicolumn{3}{|c|}{ Mesquite } & \multicolumn{3}{|c|}{ Juniper } & \multicolumn{3}{|c|}{ Pricklypear } \\
\hline & \multirow{2}{*}{$\begin{array}{c}\text { Area } \\
\left(\text { ha } \times 10^{6}\right)\end{array}$} & \multicolumn{2}{|c|}{$\mathrm{BB}$ treatable } & \multirow{2}{*}{$\begin{array}{l}\text { Area } \\
\left(\text { ha } \times 10^{6}\right)\end{array}$} & \multicolumn{2}{|c|}{ BB treatable } & \multirow{2}{*}{$\begin{array}{c}\text { Area } \\
\left(\text { ha } \times 10^{6}\right)\end{array}$} & \multicolumn{2}{|c|}{ BB treatable } \\
\hline & & $\left(\right.$ ha $\left.\times 10^{6}\right)$ & $(\%$ total $)$ & & $\left(\right.$ ha $\left.\times 10^{6}\right)$ & $(\%$ total $)$ & & $\left(\right.$ ha $\left.\times 10^{6}\right)$ & $(\%$ total $)$ \\
\hline Panhandle & 0.624 & 0.463 & 74 & 0.204 & 0.107 & 52 & 0.315 & 0.261 & 83 \\
\hline South Plains & 0.619 & 0.342 & 55 & 0.194 & 0.137 & 71 & 0.301 & 0.248 & 83 \\
\hline Plains & 1.450 & 0.581 & 40 & 0.548 & 0.293 & 54 & 0.663 & 0.467 & 70 \\
\hline Far West & 2.306 & 1.221 & 53 & 0.747 & 0.223 & 30 & 0.726 & 0.407 & 56 \\
\hline Central & 0.608 & 0.273 & 45 & 0.505 & 0.117 & 23 & 0.217 & 0.075 & 35 \\
\hline West Central & 2.464 & 0.976 & 40 & 1.484 & 0.586 & 40 & 2.271 & 1.184 & 52 \\
\hline Southwest & 0.648 & 0.191 & 29 & 1.806 & 0.419 & 23 & 0.859 & 0.345 & 40 \\
\hline Coastal Bend & 0.150 & 0.089 & 59 & 0.005 & 0.005 & 100 & 0.074 & 0.037 & 50 \\
\hline South & 4.052 & 1.608 & 40 & 0 & 0 & N/A & 3.896 & 1.549 & 40 \\
\hline Total & 12.921 & 5.745 & 44 & 5.493 & 1.888 & 34 & 9.322 & 4.573 & 49 \\
\hline
\end{tabular}

mates for each brush species are also shown in Table 2. Since the counties used to obtain these estimates represented more than $50 \%$ of the total number and area of counties in most Extension Districts, the values provided in Table 1 could be used to obtain a rough estimate of the total area and total potential Brush Busters area within each district. If this were done, the total area across all 9 Extension Districts where Brush Busters could be applied would clearly exceed the estimates obtained from the useable responses. However, such extrapolations need to be treated with caution,

Table 1 indicates that, overall, approximately $44 \%$ of mesquite, $34 \%$ of juniper and $49 \%$ of pricklypear could be treated using Brush Busters. In each case, 3 Extension Districts represent about two thirds of the estimated Brush Busters treatable area. For mesquite, the South, Far West and West Central Extension Districts represent $66 \%$; for juniper, West Central, Southwest and Plains represent $69 \%$; and for pricklypear, the South, West Central and Plains represent $70 \%$ of the estimated treatable area.

Information was also requested about the area treated annually using Brush Busters from 1995 through 1998, and how the 1998 estimates of Brush Busters coverage compared with the area of other types of brush control treatments (Tables 3 and 4 , respectively). Because the estimates presented in Tables 3 and 4 are based on useable responses only, the total area of the 91 counties providing useable responses was also included. The reason for the differences in the total number of counties and area between Table 2 and Tables 3 and 4 , is that not all counties that provided useable estimates of total area of brush and Brush Busters treatable area also provided useable estimates of the total area treated in 1998.
It is apparent from Table 3 that the usable survey responses indicated that over 422,455 ha of brush have been treated using Brush Busters between 1995 and 1998, representing approximately $1.6 \%$ of the total area of the counties used to obtain these estimates. Of the treated area about $78 \%$ was associated with the treatment of mesquite, $10 \%$ was juniper, and $12 \%$ was pricklypear. Of the 329,024 ha of mesquite treated, $27 \%$ occurred in the South West district, $21 \%$ in the West Central district, $14 \%$ in both the Central and Coastal Bend districts. According to the information analyzed, the largest portion of the 43,375 ha of juniper treated occurred in the Panhandle District $(33 \%)$, followed by the West Central (24\%), Plains (19\%), and the Southwest (15\%). In the case of pricklypear, the greatest proportion of the 50,056 ha treated occurred in the West Central district (44\%), followed by the Southwest (28\%), Rolling Plains (9\%) and Central (9\%) districts. While the Extension Agents reported no clear trend in the application of Brush Busters from 1995 through 1997 (except for juniper), there was a substantial increase in its application between 1997 and 1998: mesquite (69\%), juniper (87\%), and pricklypear (143\%).

Despite these increases, the potential for the use of Brush Busters has clearly not been realized. Table 3 indicates that the area treated between 1995 and 1998, represents a small fraction of the estimated Brush Busters treatable area; mesquite representing about $11 \%$ and juniper and pricklypear both about $3 \%$ of the additional potentially treatable area. It should be noted that the estimates of total treatable area for each species based on the photographic thresholds (Table 1), are higher than the sum of the treated and additional potentially treatable area presented in Table 3. The reason for this is that more counties provided useable estimates for the question relating to the photographic thresholds than to the questions about areas treated in 1995 through 1998. Table 1 suggests that, with the exception of juniper, the estimated potential Brush Busters treatable area for each species might be substantially greater than the estimates presented in Table 3.

From Table 4 it is apparent that Brush

Table 2. Total area of the Extension Districts included in the survey and the area and number of responding counties used to estimate the area of Brush Busters treatable area in each District.

\begin{tabular}{lccccc}
\hline \hline & & \multicolumn{4}{c}{ Responding counties } \\
\cline { 2 - 6 } District name & $\begin{array}{c}\text { Area of District } \\
\left(\text { ha } \times 10^{6}\right)\end{array}$ & $\left(\right.$ ha x $\left.10^{6}\right)$ & Area* $^{*}$ & Number & $(\%)$ \\
\hline Panhandle & 5.275 & 2.194 & 42 & 8 & 38 \\
South Plains & 4.825 & 2.733 & 57 & 11 & 55 \\
Plains & 5.782 & 3.004 & 52 & 13 & 52 \\
Far West & 12.718 & 6.410 & 50 & 10 & 43 \\
West Central & 5.965 & 5.430 & 91 & 21 & 91 \\
Central & 4.948 & 3.144 & 64 & 14 & 67 \\
Southwest & 5.620 & 3.698 & 66 & 15 & 71 \\
Coastal Bend & 4.372 & 1.630 & 37 & 10 & 39 \\
South & 6.516 & 4.265 & 65 & 109 & 50 \\
Total & 56.021 & 32.508 & 58 & 57
\end{tabular}

*Area of responding counties as a percentage of the total area of the Extension District.

$* * \mathrm{~N}$ is the number of counties used to derive the values for each Extension District; $\mathrm{N}$ as a percentage of the total number of counties in each district is shown in parentheses. 
Table 3. Estimated area (ha) treated using Brush Busters from 1995 through 1998, and the estimated additional potentially treatable area.

\begin{tabular}{lrrrrrrr}
\hline \hline Brush Type & $\begin{array}{r}1995 \\
\text { (ha) }\end{array}$ & $\begin{array}{c}1996 \\
\text { (ha) }\end{array}$ & $\begin{array}{c}1997 \\
\text { (ha) }\end{array}$ & $\begin{array}{c}1998 \\
\text { (ha) }\end{array}$ & $\begin{array}{c}\text { Total treated } \\
\text { (ha) }\end{array}$ & $\begin{array}{c}\text { Additional } \\
\text { (ha) }\end{array}$ & $\begin{array}{c}\text { County area* } \\
\text { (ha, \%) }\end{array}$ \\
\hline Mesquite & 65,903 & 55,596 & 77,175 & 130,350 & 329,024 & $3,031,254$ & \\
Juniper & 3,248 & 7,187 & 11,463 & 21,477 & 43,375 & $1,558,417$ & $(47 \%)$ \\
Pricklypear & 9,684 & 7,969 & 9,430 & 22,973 & 50,056 & $1,614,266$ \\
Total & 78,835 & 70,752 & 98,068 & 174,800 & 422,455 & $6,203,937$ & $26,519,917$ \\
\hline
\end{tabular}

*Area (ha) of the 91 counties used for this analysis, and the percentage contribution of this area to the total area of all the counties included in the study.

Table 4. Estimated area (ha) treated and percentage of total area of mesquite, juniper, and pricklypear using various brush management treatments in 1998.

\begin{tabular}{|c|c|c|c|c|c|c|c|c|c|c|c|}
\hline \multirow[t]{2}{*}{ Brush Type } & \multicolumn{2}{|c|}{ Brush Busters } & \multicolumn{2}{|c|}{ Aerial Spray p } & \multicolumn{2}{|c|}{ Mechanical } & \multicolumn{2}{|c|}{ Prescribed Fire } & \multicolumn{2}{|c|}{ Total } & \multirow{2}{*}{$\begin{array}{c}\text { County area } \\
\text { (ha, \%) }\end{array}$} \\
\hline & (ha) & $(\%)$ & (ha) & $(\%)$ & (ha) & $(\%)$ & (ha) & $(\%)$ & (ha) & $(\%)$ & \\
\hline Mesquite & 130,350 & 34 & 56,654 & 15 & 138,999 & 36 & 55,424 & 15 & 381,427 & 57 & \\
\hline Juniper & 21,477 & 13 & 0 & 0 & 84,113 & 52 & 56,152 & 35 & 161,742 & 24 & $(47 \%)$ \\
\hline Pricklypear & 22,973 & 19 & 19,741 & 16 & 29,725 & 25 & 48,685 & 40 & 121,125 & 18 & \\
\hline Total & 174,800 & 26 & 76,395 & 12 & 252,838 & 38 & 160,261 & 24 & 664,294 & 100 & $26,519,917$ \\
\hline
\end{tabular}

*Area (ha) of the 91 counties used for this analysis, and the percentage contribution of this area to the total area of all the counties included in the study.

Busters treated area represented a significant proportion of the total area of brush treatments in 1998, especially in the case of mesquite $(34 \%)$, and to a lesser extent for juniper $(13 \%)$ and pricklypear $(19 \%)$. This is significant because mesquite treatments represented $57 \%$ of the total estimated area treated in 1998 in the 91 counties used for this analysis. While mechanical treatment was applied over a greater area than Brush Busters for mesquite, the increasing trend in the application of Brush Busters treatments for mesquite (Table 3 ), suggests that the proportional use of the 4 treatments included in Table 4 may change significantly in the future, especially for mesquite. Mechanical treatment was clearly the dominant method $(52 \%)$ used for controlling juniper, and fire was the most commonly used method (40\%) for controlling pricklypear. Thus, while there has been an increase in the application of Brush Busters for controlling juniper and pricklypear, the data in Tables 1,3 , and 4 indicate that mesquite presents the greatest potential for increasing the use of Brush Busters treatments.

To ascertain the perceived efficacy of Brush Busters, the Extension Agents were asked to rank their perceptions about the effectiveness of this brush control technique for achieving 3 range management objectives (Fig 4). Most ranked Brush Busters as being above average in its effectiveness for improving forage supply, wildlife habitat and rangeland health, but consistently considered it to be less effective for improving wildlife habitat, than for improving forage supply and rangeland health. This is somewhat surprising given the central role of individual plant treatment (IPT) in the brush sculpting approach to wildlife habitat improvement (Ueckert 1997). However, this finding appears to be consistent with variations in perceived landowner interests in Brush Busters. Figure 5 represents Extension Agents' rankings of their perceptions about the interest of various types of rangeland managers in Brush Busters relative to other rangeland improvement practices. Although the mean responses from the Extension Districts varied (West Central reported the highest landowner interest and the Plains and Far West the lowest), overall, livestock producers appear to have expressed a somewhat greater interest than wildlife ranchers in Brush Busters.

To determine why Brush Busters has become popular, Extension Agents were asked to list specific reasons for landowner and their own interests in this approach to brush management. Table 5 shows the number of times a particular characteristic of Brush Busters was identified as favor-

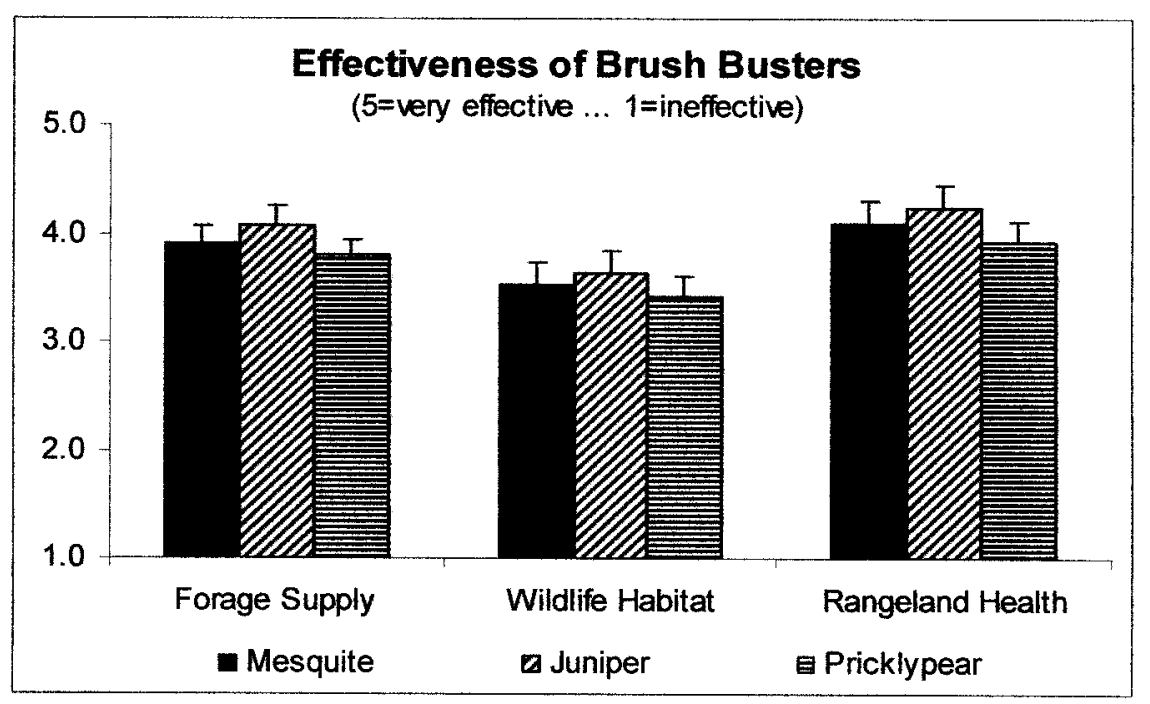

Fig. 4. Perceived effectiveness of Brush Busters for achieving three common rangeland management objectives. (Data dispersion bars represent $95 \%$ confidence limits.) 


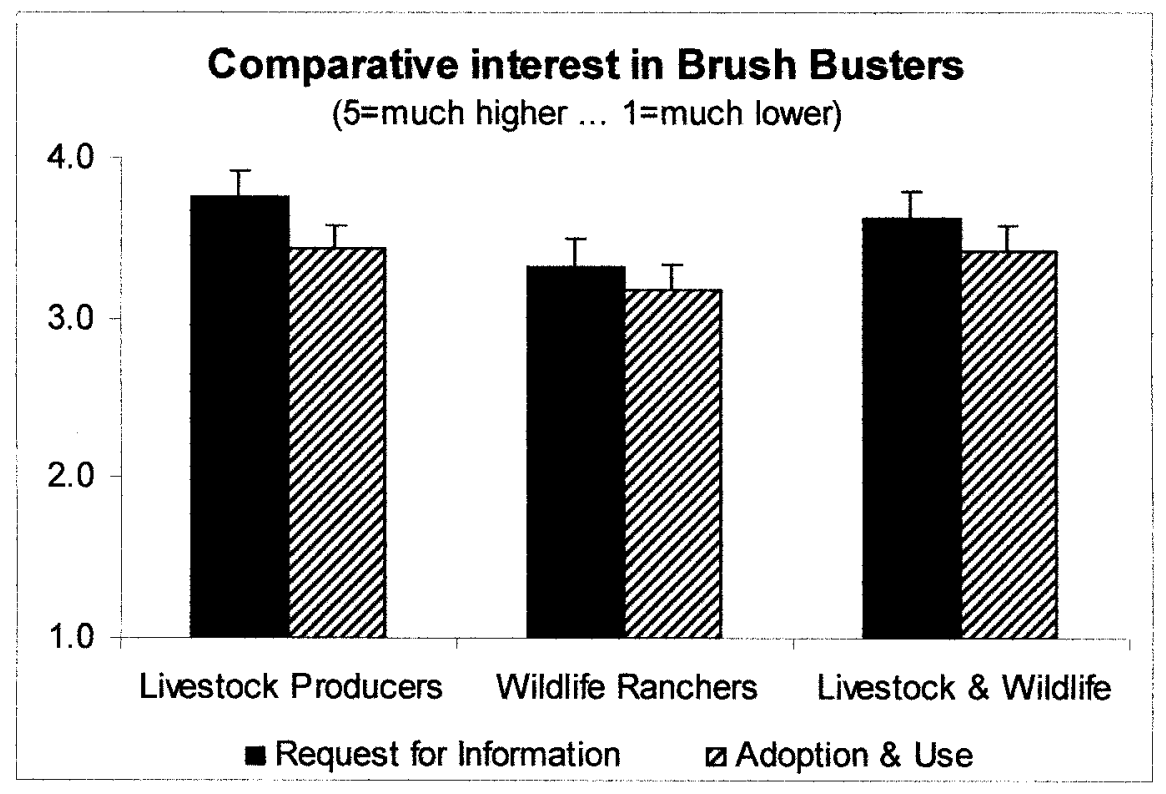

Fig. 5. Perceived interest of landowners in Brush Busters compared to other rangeland improvement practices. (Data dispersion bars represent 95\% confidence limits.)

able. The Extension Agents indicated that the relatively low cost, convenience, selectivity and effectiveness of Brush Busters for controlling unwanted plants are the most important reasons why landowners are interested in this approach to brush control. While these factors are also important to Extension Agents, other factors such as readily available informa- user-friendly information about the program is clearly a key factor for the rapid increase in interest in this approach to brush control.

To further determine why landowners have so readily adopted the Brush Busters approach to brush control, Extension Agents were asked to indicate the extent to which IPT had been promoted in the past (Fig. 6). At the time of the survey, the majority of responding counties were promoting IPT for brush control, either through dissemination of information $(88 \%)$, field days $(59 \%)$, or demonstration sites $(69 \%)$. However, these levels of promotion were not uniform across all Extension Districts. On average, the proportion of counties promoting IPT ranked as follows: West Central (93\%), Southwest (88\%), Plains (79\%), Central (75\%), Panhandle (74\%), Far West (72\%), Coastal bend $(64 \%)$, South $(59 \%)$, and South Plains (46\%). Also important is that the majority of Extension Agents (83\%) indicated that IPT for brush control had been promoted in their counties before the advent of Brush Busters. Therefore, factors other than the active promotion of IPT appear to be responsible for the high adoption rate of this type of brush control approach after 1995. As previously indicated (Table 5), the Extension Agents considered the ease of access to user-friendly information about Brush Busters to be a major benefit of the program.

Table 5. Number of times Extension Agents listed specific reasons for landowner and Extension Agents interest in Brush Busters.

\begin{tabular}{|c|c|c|c|c|c|c|c|c|c|c|}
\hline Perceived reasons for landowner interest & Panhandle & $\begin{array}{l}\text { South } \\
\text { Plains }\end{array}$ & Plains & $\begin{array}{c}\text { Far } \\
\text { West }\end{array}$ & Central & $\begin{array}{c}\text { West } \\
\text { Central }\end{array}$ & $\begin{array}{l}\text { South- } \\
\text { west }\end{array}$ & $\begin{array}{c}\text { Coastal } \\
\text { Bend }\end{array}$ & South & Total \\
\hline Relatively low cost & 3 & 4 & 8 & 2 & 2 & 0 & 2 & 8 & 4 & 33 \\
\hline Convenient, easy to apply, clear guidelines & 3 & 0 & 4 & 3 & 1 & 0 & 1 & 10 & 7 & 29 \\
\hline Selective, little herbicide drift, environmentally safe & 4 & 2 & 5 & 1 & 1 & 1 & 3 & 6 & 5 & 28 \\
\hline Effective, predictable, high \% kill & 2 & 1 & 5 & 0 & 1 & 0 & 2 & 9 & 4 & 24 \\
\hline Can treat small areas, increases flexibility and affordability & 0 & 0 & 5 & 0 & 0 & 0 & 2 & 5 & 0 & 12 \\
\hline Improves rangeland, forage production, and carrying capacity & 3 & 0 & 1 & 0 & 1 & 0 & 1 & 2 & 2 & 10 \\
\hline Little hired labor required & 0 & 0 & 2 & 0 & 0 & 0 & 0 & 6 & 1 & 9 \\
\hline Less use of herbicide than aerial spraying & 2 & 0 & 1 & 0 & 0 & 0 & 0 & 2 & 1 & 6 \\
\hline Large time window for application due to flexibility & 1 & 0 & 1 & 0 & 0 & 0 & 0 & 3 & 0 & 5 \\
\hline Suitable for containing brush invasion and density & 0 & 0 & 0 & 0 & 0 & 0 & 1 & 0 & 4 & 5 \\
\hline Little or no additional equipment needed & 1 & 0 & 1 & 0 & 0 & 0 & 0 & 2 & 0 & 4 \\
\hline Other & 0 & 1 & 7 & 0 & 2 & 0 & 2 & 5 & 5 & 22 \\
\hline Reasons for Extension Agents interest & Panhandle & $\begin{array}{l}\text { South } \\
\text { Plains }\end{array}$ & Plains & $\begin{array}{c}\text { Far } \\
\text { West }\end{array}$ & Central & $\begin{array}{l}\text { West } \\
\text { Central }\end{array}$ & $\begin{array}{c}\text { South- } \\
\text { west }\end{array}$ & $\begin{array}{c}\text { Coastal } \\
\text { Bend }\end{array}$ & South & Total \\
\hline Effective, high \% kill, predictable quick results, practical & 5 & 3 & 5 & 2 & 4 & 7 & 6 & 1 & 4 & 37 \\
\hline Easily available information, training, and demonstrated results & 1 & 1 & 2 & 2 & 3 & 5 & 3 & 1 & 6 & 24 \\
\hline Relatively low cost & 2 & 4 & 2 & 1 & 2 & 6 & 2 & 2 & 1 & 22 \\
\hline Convenient, easy to apply, clear guidelines & 3 & 0 & 1 & 1 & 2 & 4 & 4 & 1 & 3 & 19 \\
\hline Selective, control herbicide placement, environmentally safe & 0 & 2 & 0 & 0 & 3 & 4 & 3 & 2 & 1 & 15 \\
\hline Can treat small areas & 1 & 0 & 3 & 1 & 2 & 2 & 3 & 2 & 0 & 14 \\
\hline Improves rangeland, forage production, and carrying capacity & 0 & 3 & 0 & 0 & 0 & 2 & 0 & 0 & 1 & 6 \\
\hline Meets landowners needs & 0 & 0 & 0 & 1 & 1 & 3 & 1 & 0 & 0 & 6 \\
\hline Little hired labor required & 1 & 0 & 1 & 0 & 0 & 0 & 0 & 0 & 3 & 5 \\
\hline Can be used around building, corrals, fences, watering places & 0 & 0 & 0 & 2 & 0 & 1 & 0 & 0 & 1 & 4 \\
\hline Other & 0 & 4 & 5 & 3 & 3 & 3 & 3 & 2 & 3 & 26 \\
\hline
\end{tabular}




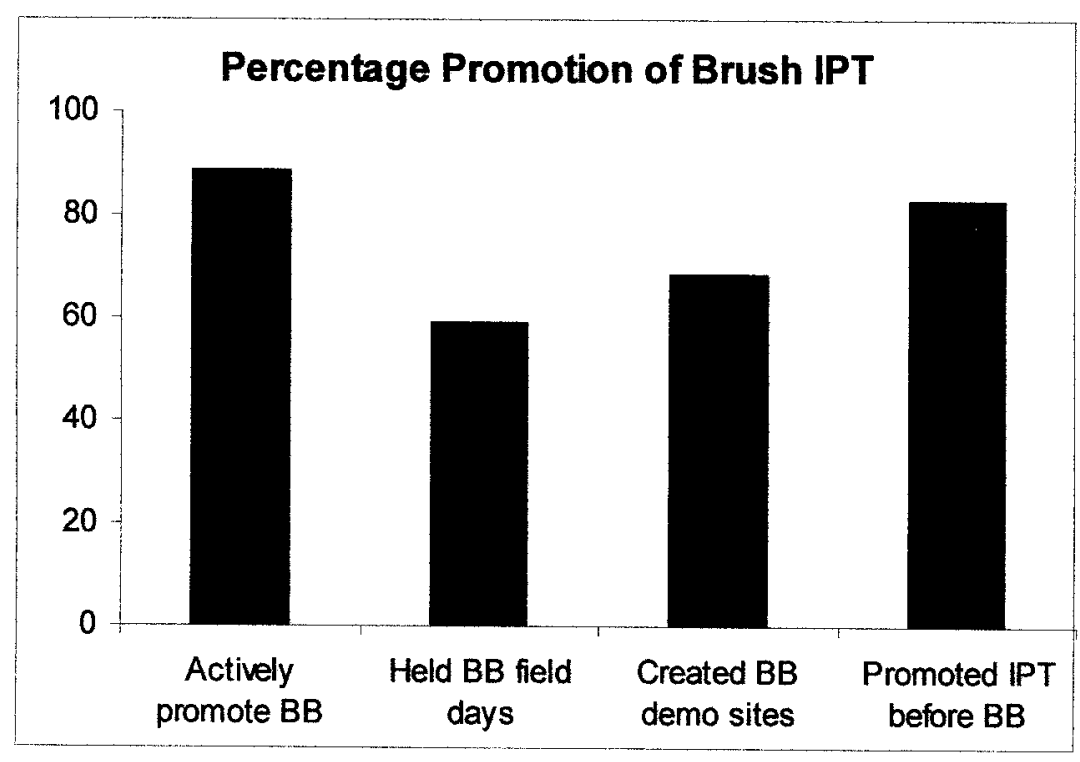

Fig. 6. Percentage of responding counties that have promoted individual plant treatments for brush control.

One of the novel aspects of the Brush Busters program was the development and dissemination of a wide array of information sources about this IPT approach to brush management, including notebooks, brochures, videos, and CDs, all of which bear the easily recognizable Brush Busters logo and name. Because of these numerous sources of information, Extension Agents were asked to identify which sources had been provided to their office (Fig. 7). The simply worded trifold brochures for the mesquite, juniper and pricklypear programs (McGinty and Ueckert 1995, 1996, Ueckert and McGinty 1997) were reported to be most widely received, as was the 3-ring binder about the program. Field days evidently have also provided an important source of information for nearly $70 \%$ of the responding Extension Agents, and the mesquite video and magazine articles were also reported to have been received as sources of information by over $50 \%$ of the respondents.

Finally, the Extension Agents were asked to identify brush species not currently covered under Brush Busters that could be managed with herbicide applications to individual plants. The main species listed and the number of times that they were listed were: huishache (Acacia smallii (L.) Willd.) - 15, mainly in the Coastal Bend district; Yucca sp. - 8, mainly in the Panhandle and South Plains districts; persimmon (Diospyros texana Scheele) - 5, mainly in the West Central and South districts; and saltcedar Liebm.), greenbriar (Smilax sp.), sand sage (Artemesia filifolia Torr.), catclaw (Accaci greggii Grey), African rue (Peganum harmala L.), willow baccharis (Baccharis salicina (R.\&P.) Pers.), lotebush (Zizyphus obtusifolia (T.\&G.) Gray), blackbrush (Acacia rigidula Benth.), and Chinese tallow (Sapium sebiferum (L.) Roxb.).

\section{Discussion and Conclusion}

The adoption of new or existing technology by land managers is affected by many factors other than its efficacy, including the land managers' age, education, income, goals, and level of community participation, the size and tenure status of the land, as well as the Extension, print media, and radio contact to which they have been exposed. While the influence of some of these factors may be relatively easily determined, psychological factors are often less tangible but more consequential than physical or economic factors in determining which technologies are implemented by land managers.

In our study we attempted to identify some of these factors by surveying County Extension Agents to determine how their own and landowners' interest in alternative brush management practices are influenced. The reason why we targeted Extension Agents and not landowners in

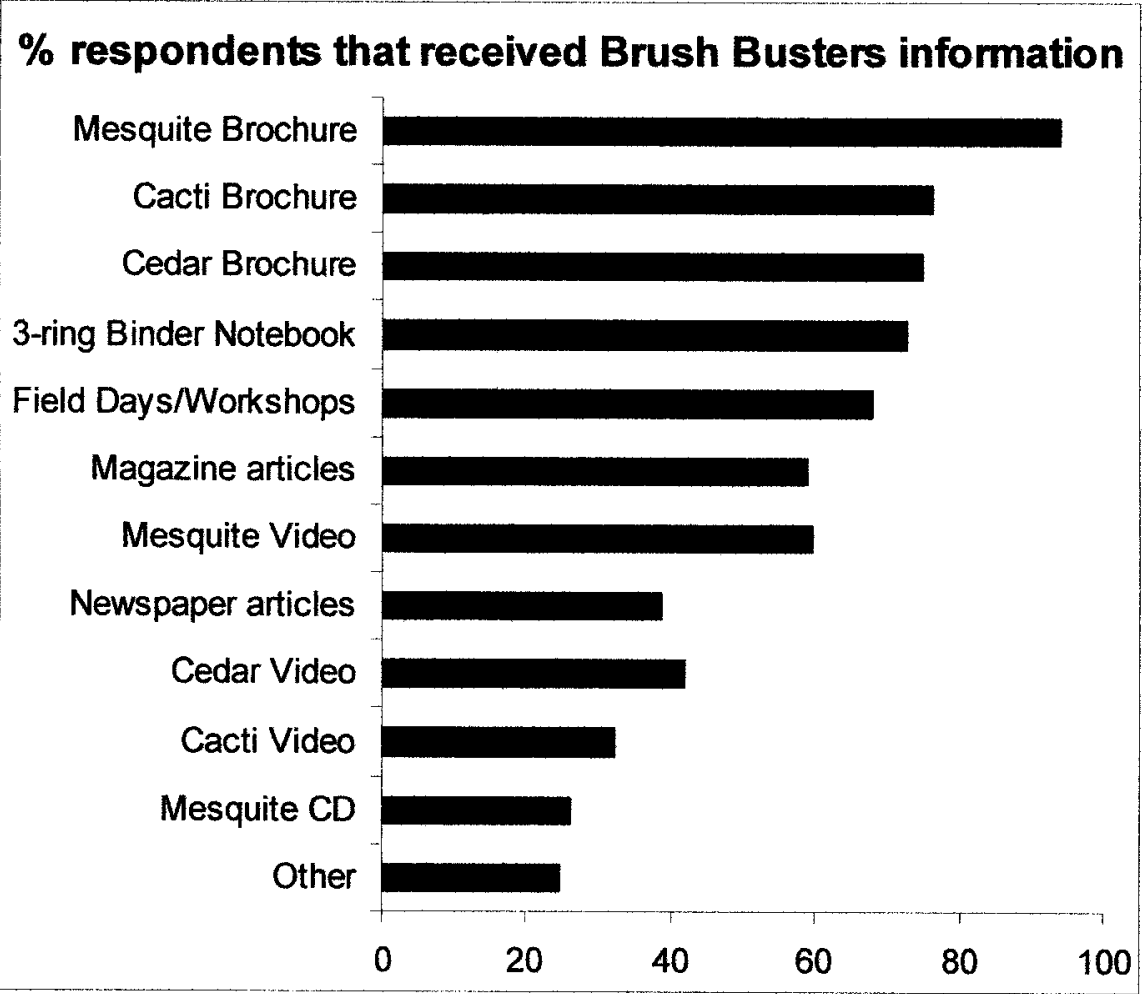

Fig. 7. Sources of information about Brush Busters received by the Extension Agents. 
this survey is that, because of the large areas that they service, it was logistically simpler to extract statewide information from the Extension Agents than from individual landowners. While the results of the survey might have been different had landowners been interviewed, we feel that because Extension Agents interact with numerous landowners, the information obtained from them provides a good first approximation of the factors that influence landowners' perceptions of alternative brush management practices.

Due to the increasing brush density on many rangelands and the associated negative impact on rangeland productivity for livestock, wildlife, and water production, it is critical to promote biologically effective, environmentally friendly, and economically efficient brush control technologies that have a high probability of being implemented by managers with a wide array of objectives. However, rangeland ecosystems are frequently complex and their responses to rangeland management practices are often delayed. This creates a challenge for rangeland management professionals attempting to promote sustainable management practices because most people are impatient to see evident rewards for their investments. Aversion to adopting new technologies tends to increase when responses are not only slow but also depend on environmental vagaries.

According to our study, Brush Busters has become popular because it is perceived to be an inexpensive, convenient, safe, effective and predictable method for controlling brush. Perhaps even more important to its success is the ready availability of user-friendly information about the program. Brush Busters was not developed strictly as a research program, but rather as a collaborative extension/research program between the TAEX and TAES in response to a rapidly increasing interest during the early 1990s in herbicide-based individual plant treatments (IPT) for controlling brush. While technical knowledge about tactical brush management was well established prior to this period, a vehicle for easily and widely disseminating this knowledge was lacking before the inception of Brush Busters. Thus, the major impetus for the development of Brush Busters was to disseminate pertinent information about IPT in order to reduce the need for repeated verbal communication. The partnership between TAEX, TAES, Dow AgroSciences LLC, and others resulted in widespread distribution of userfriendly information about Brush Busters across most of Texas, and several other States. Of particular importance were the simple tri-fold brochures (McGinty and Ueckert 1995, 1996, Ueckert and McGinty 1997), which greatly facilitated the dissemination of the information by Texas County Extension Agents. In addition, the notebook, videos, and compact disk produced about Brush Busters and the numerous field demonstrations enabled Extension Agents to easily inform themselves and others about the program.

The simplicity, predictability and cost effectiveness of the brush control methods promoted by Brush Busters, together with the collaborative agency/private sector technology "marketing" effort has resulted in rapid exposure throughout Texas, and successful technology transfer of IPT for brush control. Moreover, our survey showed that the area treated using Brush Busters methods between 1995 through 1998 represented only a small fraction of the total treatable area in Texas. In addition to the areas representing treatable heights and densities of plants, IPT could also be used to maintain reduced brush densities in areas where stands of brush that are initially too dense or too tall for IPT are first treated with alternative methods, such as broad scale herbicide or mechanical treatments. Thus, the potential for future implementation of the Brush Busters approach to brush control in Texas is substantial, not only for mesquite, juniper and pricklypear, but also for other problematic woody plants. In addition, while efforts to promote this approach to brush management have focused on Texas, there is substantial potential for implementing the program in many other States where the encroachment of brush and invasive species pose a problem for rangeland managers.

Our findings suggest that much greater emphasis needs to be placed on how information about rangeland management technologies is imparted to Extension Agents and land managers in order to increase the adoption rates of technologies that facilitate ecologically sound rangeland management. The agency/industry "marketing" partnership that propelled the spread of information about Brush Busters appears to be a key determinant for the rapid acceptance of new technology. In addition, rangeland management technologies that can be easily understood, are inexpensive, and which have relatively rapid and predictable results are more likely to be adopted by land managers than costly or complex strategies with delayed or uncertain responses. Thus in order for new tech- nologies to be rapidly adopted, rangeland researchers and Extension Agents should focus on providing simple messages about their technology and they should place greater emphasis on the visible short-term benefits rather than the long-term advantages of the technology.

\section{Literature Cited}

Archer, S. 1989. Have southern Texas savannas been converted to woodlands in recent history? Amer. Natur. 134:545-561.

Archer, S. 1994. Woody plant encroachment into southwestern grasslands and savannas: rates, patterns and proximate causes, $\mathrm{p}$. 13-68. In: M. Vavra, W. Laycock, and R. Pieper (eds.), Ecological implications of livestock herbivory in the West. Soc. Range Manage. Denver, Colo.

Archer, S. and Chris Stokes. 2000. Stress, distribution and change in rangeland ecosystems, p. 17-38. In: Olafur Arnalds and Steve Archer (eds.), Rangeland desertification. Kluwer Acad. Publ. Dordrecht, The Netherlands.

Barao, S.M. 1992. Behavioral aspects of technology adoption. J. Ext. 30:13-15.

Bovey, R.W. 1998. A fifty-year history of the weed and brush program in Texas and suggested future directions. Texas Agr. Exp. Sta. Bull. B-1729. College Station, Tex.

Dillman, D.A. 1978. Mail and telephone surveys: The total design method. John Wiley and Sons. New York, N.Y..

Douglass, J.E. 1983. The potential for water yield augmentation from forest management in the Eastern United States. Water Resource Bull. 19:351-358

Fliegel, F.C. 1993. Diffusion research in rural sociology. Greenwood Press, Westport, Conn.

Fulbright, T.E. 1997. Designing shrubland landscapes to optimize habitat for whitetailed deer, p. 61-66. In: Dale Rollins, Darrell N. Ueckert, and Cristy G. Brown (eds.), Proc. Brush Sculptors Symposium. Texas A\&M University Res. and Ext. Center, San Angelo, Tex.

Hanselka, C.W., W.T. Hamilton, and B.S. Rector. 1996. Integrated brush management systems in Texas. Texas Agr. Ext. Serv. Leaflet L-5164. College Station, Tex.

Hanselka, C.W., J.C. Paschal, and C.L. Ricahrdson. 1991. South Texas ranching: A profile. Texas Agr. Exp. Serv. Bull. B-5010. College Station, Tex.

Hanselka C.W., A. McGinty, B.S. Rector, R.C. Rowan and L.D. White. 1990. Grazing and brush management on Texas rangelands: An analysis of management decisions. Texas Agr. Ext. Service Tech. Rep., College Station, Tex. 
Jofre, R. and S. Randal. 1993. How tree cover influences the water balance of Mediterranean rangelands. Ecol. 74:570-582.

Kreuter, U.P., S.R Archer, and C.J. Scifres. 1999. Bio-economic basis for woody plant management, p. 842-843. In: David Eldridge and David Freudenberger (eds.), Proc. $6^{\text {th }}$ Int. Rangeland Congress, Townsville, Australia.

Kreuter, U.P., R.C. Rowan, J.R. Conner, J.W. Stuth and W.T. Hamilton, 1996. Grazinglands Alternative Analysis Tool (GAAT): An economic analysis tool for range improvement. J. Range Manage. 49:464-469.

McGinty, A. and D. Ueckert. 1995. Brush Busters - how to beat mesquite: A safe and effective three-step way to control mesquite on small or large areas. Texas Agr. Ext. Serv. and Texas Agr. Exp. Sta. Leaflet L-5144.

McGinty, A. and D. Ueckert. 1996. Brush Busters - how to master cedar: Three safe and effective ways to control small cedar (juniper). Texas Agr. Ext. Serv. and Texas Agr. Exp. Sta. Leaflet L-5160.

Rowan, R.C., and L.D. White. 1994. Regional differences among Texas rangeland operators. J. Range Manage. 47:338-342
Rowan, R.C., H.W. Laedig, and L.D. White. 1994. Perceptions vs. recommendations: A rangeland decision making dilemma. J. Range Manage. 47:344-348.

Schlessinger, W.H., J.F. Reynolds, G.L. Cunningham, L.F. Huenneke, W.M. Jarrell, R.A. Virginia, and W.G. Whitford. 1990. Biological feedbacks in global desertification. Science 247:1043-1048.

Scifres, C.J. 1980. Brush management: principles and practices for Texas and the Southwest. Texas A\&M Univ. Press, College Station, Tex.

Scifres, C.J., J.L. Mutz, G.A. Rasmussen, and R.P. Smith. 1983. Integrated brush management systems (IBMS): Concepts and potential technologies for running mesquite and whitebrush. Texas Agr. Exp. Sta. Bull. B-1450, College Station, Tex.

Teague, W.R., R.J. Ansley, U.P. Kreuter, J.M. McGrann and W.E. Pinchak. 2001. Economics of managing mesquite with prescribed fire and root-killing herbicides: a sensitivity analysis. J. Range Manage. 54:553-560.

Thurow, T.L., A.P. Thurow, and M.D. Garriga. 2000. Policy prospects for brush control to increase off-site water yield. J. Range Manage. 53:23-31.
Ueckert, D.N. 1997. Brush Busters: The precursor to Brush Sculptors, p. 8-12. In: Dale Rollins, Darrell N. Ueckert, and Cristy G. Brown (eds.), Proc. Brush Sculptors Symposium. Texas A\&M University Res. and Ext. Center, San Angelo, Tex.

Ueckert, D.N. and A. McGinty. 1997. Brush Busters - how to take care of pricklypear and other cacti. Texas Agr. Exp. Sta. and Texas Agr. Ext. Serv. Leaflet L-5171.

Ueckert, D.N., W.A. McGinty, and U.P. Kreuter. 1999. Brush Busters: Marketing Prosopis management technology, p. 580-581. In: David Eldridge and David Freudenberger (eds.), Proc. $6^{\text {th }}$ Int. Rangeland Congress, Townsville, Australia.

White, L.D. 1987. Technology transfer and total ranch management. p. 125-128. In: R.S. White and R.E. Short (eds.), Proc. Fort Keogh Res. Symposium: Achieving efficient use of rangeland resources. Montana. Agr. Exp. Sta., Bozeman, Mont.

Workman, J.P. 1986. Range economics. MacMillan, New York. N.Y.

Zepada, L. 1994. Simulataneity of technology adoption and productivity. J. Agr. Resource Econ. 19:46-57. 